\title{
Role of Education for Inculcating Moral Values in New Generation: An Islamic Perspective
}

\author{
*Dr. Abdul Razzaq Azad \\ ${ }^{* *}$ Dr. Musferah Mehfooz \\ ${ }^{* * *}$ Hafiz Nasir Ali
}

\section{ABSTRACT:}

Education has been greatly emphasized in Islam. It is an important matter which forms the basis for one's life direction. Therefore, the purpose of this study is to present the Islamic educational model as a significant instrument to tackle the scary rise of immoral attitude and values in our new generation. From an Islamic perspective, knowledge is gained to actualize and perfect all dimensions of the human being and the highest and most useful model of perfection is the prophet Muhammad (SAW). Education, therefore, is an aspect that is important and must be given special attention so that the person can be molded into a human as best as possible. This paper targets the significance of education for inculcating moral values in the new generation and molding them into the ideal Muslim along with high intellect. The study would also highlight the substantial role of the education system including the academia and curriculum for instilling moral value and Islamic norms into Muslim students. In sum, several suggestions are recommended to strengthen the educational system in Pakistan, and then we could produce a nation that will be the combination of knowledge and practice and the real specimen of morality according to the teachings and main purpose of Islam.

Keywords: Islamic Perspective; Moral Values; New Generation; Education

\section{Introduction}

The rise of Muslims towards civilization in four decades was based on Islam's emphasis on learning. This is evident when one investigates the Qur'an and the customs of Prophet Muhammad (SAW), which are loaded with references to learning, training, perception, and the utilization of reason. The principal verse of the Qur'an revealed to the Prophet Peace be upon him was about the motivation for learning and gain about knowledge.

"In the name of thy Lord who created man from a clot. And thy Lord is the Most Generous Who taught by the pen, taught man that which he knew not." (Quran, 96: 15) And on another place, Allah states:

"Are those who have knowledge and those who have no knowledge alike? Only the men of understanding are mindful.” (Quran, 39:9)

*Assistant Professor, Humanities Department, COMSATS University Islamabad, Vehari Campus

**Assistant Professor, Humanities Department, COMSATS University Islamabad, Lahore Campus

${ }^{* *} \mathrm{Ph}$.D Scholar, Department of Islamic Studies, BZU, Multan 
Quran also exhorts Muslims to do scientific research:

"And who bring the truth and believe therein such are the dutiful."(Quran, 39: 33)

As the human soul from the earliest starting point has been outfitted with the learning of God, looking for information is an imperative property of man. Due to information, educating and learning winds up significant and sensible. Information from current origination is something that can be demonstrated by human reason and known in the logical and observational examination. ${ }^{1}$ It is something that can be experienced by man and can be gotten a handle by human reason. In any case, in Islam, all the undetectable perspectives, for example, qualities and religion are a piece of learning. Thusly, learning from an Islamic perspective is "the entry in the spirit of the significance and meaning of a thing". The "significance and meaning of a thing" is its correct importance got from the Holy Qur'an. ${ }^{2}$

Among the primary point of training ought to by the service of instruction in Pakistan is to create an individual with an adjusted development otherworldly, learned, enthusiastic, and substantial faculties. To accomplish this objective, an individual should love learning. Love of learning implies a push to look for information through perusing as well as through talking about, investigating, debating, or perception. The efforts of the Prophet Muhammad (SAW) and his companions in spreading the information of Islam everywhere throughout the world is highly appreciated when they have effectively changed and changed the general population from obliviousness to reality. ${ }^{3}$

In fact, knowledge in Islam is essential for a Muslim's spiritual growth and advancement. Furthermore, since knowledge is gained through the dynamic procedure of going past what one knows, it is basic for a Muslim to develop intellectually and spiritually. It additionally recommends that intellectual development without spiritual development is meaningless, and otherworldly improvement without spiritual development is all in vain.

\section{The Concept of Education in Islam}

The term education is elusive. It has been characterized or depicted in different ways or structures by numerous philosophers, savants, clinicians, teachers, educationists and so on. In actuality, philosophers aren't as simple as we may think about it as an idea. It might mean diverse things to various individuals and distinctive society. For instance, it is characterized as "a procedure, which empowers a person to modify himself to the earth." Education was envisioned by Bidmos (2003) when he opined that: "It is the process by which an individual born into a human society, learns the ways of life, which include knowledge, skills and moral values of the society, at home, community and schools, so that he can function effectively as a member of the given society."4

According to Mohammad Qutb, "education is the process to shape the holistic and balanced human. The main objective of education is to develop the potency of human's intellect, physical, emotional and spiritual towards the level of perfection. Within this process, the implementation of values has been focused on by the Islamic Philosophy of Education, in which the aspect of ethical and moral cannot be separated from 
education and the thought of Islam. It is parallel with the branches of axiology that believe education is the realm that provides values. Within the axiology of Islam itself, the knowledgeable person should be the moralistic and well-behaved person." 5

Along these lines, the fundamental point of education in Islam is to create a decent man. To accomplish this goal, Islam accentuates the purification of the soul which is the main purpose for every human activity. In this way, every demonstration of love in Islam is intended to assume a part during the time spent soul purification and at last putting man on the way of uprightness. For instance, ethics, for example, neatness, God's-awareness, reliability, modesty and shirking of any type of obscenity can be gotten from salat. Benevolence and feeling of sharing can be gotten from fasting. Perseverance and humbleness are learnt from Hajj. Be your sibling keepers is learnt from Zakat. Others like obligingness, goodness to guardians, regard to the constituted experts, the correct disposition to work and regard for the poise of work as opposed to been slothfulness are lessons that are either learnt in Islam straightforwardly or got from acts of worship. Religion is the base of any social norms, beliefs and ethics. Islam's primary focus is also on the moral agent and heavily emphasizes building moral character. But today our educational environment badly ignores religious ethics. Religion is considered a private matter instead it deals with every aspect of life. The actual spirit of Islam is destroyed. The purposive growth of the body and soul is not possible except with the help of spiritual self-purification.

Naqvi found that the human self-consisted of the spiritual and the human realm of matter both necessary for education. He concluded that our new generation should be educated (ta'dib - Arabic) to meet their human nature needs. ${ }^{6} \mathrm{Al}$-Attas elaborated that, ${ }^{7}$ the meaning of education in itstotality is inherent in the connotations term "tarbiyyah", "ta'lim", and "ta'dib" taken altogether. Tarbiyyah means to nurture, to bear, to feed, to foster, to nourish, to cause to increase growth, to rear,and to bring forth to mature produce. ${ }^{8}$ Al-Attas defined that "Ta' dibis referred to a process of instilling something into human beings and inculcation of adabin man." Three elements inherent in the concept of ta'dib, i.e., the method of education (refers to "a process ofinstilling"), a content (refers to "something"), and the recipient (refers to "human beings"). ${ }^{9}$ Unethical and immoral actions were often the consequence of abuse from inadequate character building and awareness (Johnson \& Hinton, 2018). ${ }^{10}$ Moreover, unethical behaviors further exacerbate social issues concerning high school students. ${ }^{11}$ We should become aware of others, as persons and have a vivid and sympathetic representation in the imagination of their interests and of the effects of our actions on their lives. Perhaps, those of us concerned with the issues of Moral Education must turn to moral philosophy to find the humanistic guidance which seems to be lacking in education today.

\section{Importance of Education for Promoting Morality}

Islamic highly stresses values, ethics, and morals. Morality is an attitude of a man concerning the moral law which is based on his free decision. ${ }^{12}$ Morality is a broad term that affects every aspect of our life, social, economic and political etc. Actions which 
are destructive to our society such as smuggling, telling a lie, cheating etc. are called as morally bad actions, whereas actions that ensure the dignity of a man and survival of society are morally god actions. So, morality is the art of proper behavior, it deals with human actions in terms of being right or wrong, legitimate or illegitimate. Importance of character building: Characters defined as how one behaves through the choices he or she makes. According to Aristotle Good character is a way of living life with the right conduct, concerning others and to oneself. ${ }^{13}$

Researches show that youth are careless about moral and ethical values. It is essential for developing ethics in society to enhance family integration, family-based moral values. Anangisye concluded that "policy intentions on the promotion of moral and ethical values are not in harmony with what is implemented in schools and colleges. Although moral and ethical issues have been included in the general studies' syllabus and teaching of the same is done, many students graduate with a lot of moral and ethical deficiencies"14

It would be pertinent to share that Values and Moral Values are closely related to moral education. Vokey suggested that moral education could help students to choose values that would explain moral judgement. ${ }^{15}$ According to Robert, the introduction of values education could provide imperative for developing a moral values education program and educational policies. ${ }^{16}$

Ibn Miskawayh has elaborated the characteristics of morality that "a state of the soul which moves it toward action without any need for reflection or deliberation. This state can be divided into two: The first is that which is natural and is a part of one's true disposition, such as a human who laughs excessively at any small thing that amuses him or feels sadness and sorrow in response to any small matter that afflicts him. The second is that which is borne of training and habituation, and though it may originally be a product of reflection and deliberation eventually becomes a character trait."17

Honesty and moral value are great characteristics attractive to every single individual. These characteristics make one's life worth living even though there is the disintegration of good esteems because of materialistic avarice. In Pakistan today, there is fast good debauchery cutting crosswise over grown-ups, adolescents and children in all divisions of the general public. Delinquent behaviors have de-generated the psyche of people and the mind of individuals in the general public to the degree that individuals have lost confidence in the limit of the legislature to maintain ethics and equity. Individuals are never again dedicated as self-workers, government employees, a worker in private organizations, even as educator, or understudies. All sets of principles to the extent their territories are concerned are paperwork, duty and devotion are of no importance concerning open areas are concerned. In society behaviors and actions of people denoting moral deterioration such as isolation, robbery, lack of wellbeing, violence, killing etc.

Linda, \& Eyre postulates that "findings have shown that the majority of men and women found in these acts are mostly school dropouts, youngsters from broken homes and unemployed graduates of various institutions at diverse levels. Therefore, this calls for the appropriate implementation of religious and ethical education in our schools. If 
curricular on religions, social and ethical education is well planned and developed and at the same time correctly implemented most of the above stated moral decadence would, if not completely eradicated be reduced to the minimal."18

Phenix in a work entitled "Realms of Meaning: A Philosophy of Curriculum for General Education" deals extensively with two particular "patterns of meaning" which are of interest here. Phenix argues that "The (major) aim of education is to engender an integrated outlook". He divides the "meanings" into six fundamental patterns. The two of interest and relevancy here, he terms "synnoetics" and "ethics". Synnoetics are concerned with personal and relational knowledge. He describes synnoetics as being to knowing as sympathy is to feelings. "Synnoetics are existential, concrete and direct. " Synnoetic meaning requires engagement whereas symbolics, empirics and esthetics require detachment. " Ethics are concerned with "obligation rather than fact; with personal conduct' that is based on free, responsible, deliberate decision." The final pattern is that of synoptic which Phenix describes as being "comprehensively integrative and which is to be found in such disciplines as history, religion and philosophy. ${ }^{19}$

Now a day, our education environment is based on a secular education system. People have conveyed knowledge and information but fails to strengthen their moral norms and values which results in the declination ethical psyche of the nation, whereas at the individual level it has created a lack of integrity in many. Scarcity of ideal teachers, absence of counselling between students and teachers as well as lack of objectivity in curriculum sinks into the quicksand of immorality. It is instructive to mention here that certain moral codes should be followed by a man while developing a relationship with others that would help improve a well-ordered life. The qualities of a noble human being have sagaciously interpreted by Mawdudi after a detailed study of Islamic corpus: "Self-control, generosity, mercy, sympathy, a sense of justice, breadth of vision, truthfulness, trustworthiness, integrity, respect for pledges and commitments, fairmindedness, moderation, courtesy, purity and discipline." ${ }^{20}$ Wan Daud has stated regarding this matter that "Islam abhors those vices such as hatred, rancour, cheating and encroachment on the right of others. Also, murder, theft, extortion, fornication, usury, lying, backbiting, taking of intoxicants and consumption of harmful foods are condemned. In other words, man owes to his fellow man, certain moral responsibilities that would be geared towards the enhancement of the individual and the societal goal as a recipe for a peaceful life, bearing in mind always that such good deed is a divine commandment from the Lord, whom he loves, obeys and cherishes. It goes without saying that the spiritual fraternity of a man with God and seeking moral well-being of others are central elements to Islamic religious teaching, philosophy and practice." 21

\section{Prolific Role of Teachers and Educational Institutes for Inculcating Moral Values in New Generation}

Any society that does not have enough confidence in its fundamental values to instruct the young in them or enough common sense to do so is courting disaster. The time has come for the schools to muster some courage and give moral instruction the emphasis 
and attention it so richly deserves. ${ }^{22}$ Al-Ghazali and Ibn Sina had argued that intelligence has resided in the heart. ${ }^{23}$ Their argumentation is based on several, which implied the potentiality of human intellect in the heart. To improve the human heart is by learning and understanding wholeheartedly his "curriculum", which is the Holy Qur'an. Because Allah the Almighty has designed a very appropriate curriculum for all mankind which has presented in the Holy Qur'an. ${ }^{24}$ Therefore, the Holy Qur'an and its best interpretation of the Sunnah of Prophet (SAW) should be the fundamental approach of our education system and the priority to be taught to our generation. Because both guidance Hasan emphasis on various values which are the foundation stone for every Muslims' ethical behavior like, honesty, truthfulness, justice, sound moral character, humility etc. ${ }^{25}$

Education aims to start adding up to change in a man - convictions, activities, potential, resources, considerations, articulations, desires, energies and everything identifying with that individual; at the end of the day the adjusted advancement of the entire identity of a person - the specialist of Allah. ${ }^{26}$ It looks to persuade each individual from society to advance and support everything great (right) and discourage and forbid evil (wrong). ${ }^{27}$ Instructors additionally should dependably indicate admirable character to the understudies. The purpose behind this is growing up, while at school children are effortlessly affected by the general population around them particularly instructors. Kids likewise regularly make instructors their good example to take after separated from their folks. Along these lines, it is appropriate for teachers to indicate great practices and move toward becoming good examples for the understudies. Educators should know the premiums of youngsters at that age to conjure the kid's enthusiasm for learning. ${ }^{28}$ But, tragically that some of our educators consider their expert capacity isolate from any good or moral esteems. This recognition repudiates with Islamic lessons that see educators as the profound source and additionally proficient direction. Therefore, the educator's preparation program ought to be considered. The right comprehension of the idea of information and the significance of morals ought to be appropriately instructed in the preparation program. In like manner, love of learning ought to be a piece of the instructor's preparation program. The school are a great source to promote ethics, therefore, in this regard, a talk will be organized for parents, during Parents Teachers' Association (PTA) and ethical issues can be discussed. School specialist must check the basis behind an understudy looking for a move into the school. This influences the school to know to regardless of whether it is because of bad conduct or rejection that is making the understudies look for exchange to the new school. In this way, nonconformist understudies would be easily seen and denied move into another school in other to demoralize other individuals from acting mischievously. ${ }^{29}$

The purpose of the study is to focus on the importance of Moral or Noble Values and their inculcation. History is one of the appropriate subject matters for moral exercise among the young generation, and history plays an important role in the curriculum. ${ }^{30}$ Appropriate teaching strategies should be employed in discussing moral, ethical, and socio-science-technology issues. These should be in accordance with the student's 
moral development to lead to meaningful learning. The Moral or Noble Values must be a major component of the curriculum and are as basic and important as is the teaching of subject areas. The goals of education placed too much emphasis on material gains; those served by education were reduced to merely the seeking of knowledge. Knowledge without Moral or Noble Values foundation was incapable of arriving at the truth and students were incapable of developing the balance of character and personality needed to meet the real-life challenges. ${ }^{31}$ It is true that in education in general in the modern era there has been an imbalance in favor of the cognitive. However, 'reform' through the elimination of the cognitive, so widely practiced in the schools today, is getting us nowhere. We need rather heighten the relevance of the cognitive, increase its intensity, where necessary, and supplement it with the missing affective and behavioral elements. Neglect of the cognitive does not lead to genuine reform in education. This applies both to the education of school students and the education of their teachers. ${ }^{32}$

\section{Conclusion}

All children are born with various potentials and with different possibilities which will develop if given the correct incitement. To raise and guide a youngster so they have an honorable identity isn't a simple undertaking. The advancement of a child mind for instance is particularly reliant upon the impact of the condition in the early improvement of the child. Training has dependably been a noteworthy plan in a child's improvement program, as it can realize social, passionate, and otherworldly change towards better personal satisfaction. By featuring the idea of instruction in Islam, it is almost certainly that training at each level in Pakistan ought to be updated and reinforced. Despite concentrating on substance and technique, the right comprehension of the idea of information and the educating and learning methodology ought to be improvised. Aside from instructors and school expert, guardians assume an essential part of the training. Since guardians positively know their youngsters better, it is extremely gainful if they can include in their kids' training specifically checking their social life.

\section{References}

${ }^{1}$ Feibleman,J. K. (1999). Understanding philosophy: A popular history of ideas. London: Souvenir Press. ${ }^{2}$ Al-Attas, S. M. N. (1991). The concept of education in Islam: a framework for an Islamic philosophy of education. Kuala Lumpur: ISTAC.

3 Ahmad, V. D. (1983). 'Ulum Al-Qur'an: An introduction to the sciences of the Qur'an. United Kingdom: The Islamic Foundation.

${ }^{4}$ Bidmos, M. (1984). Religious teacher education: Islamic perspective. Muslim Education Quarterly, 2(1), 52-64.

${ }^{5}$ Mok Soon Sang. (2004). Ilmu Pendidikan untuk KPLI (Komponen 3: Profesionalisme Keguruan) Sekolah Rendah. Subang Jaya: Kumpulan Budiman Sdn. Bhd.P.97

${ }^{6}$ Naqvi, A.S. (1989). A new islamic scientific theory of the human self and its states of consciousness. International Seminar on Islamic Philosophy and Science. May 30-June 2, 1989, Pulau Pinang, Malaysia.

${ }^{7}$ Wan Mohd Nor, W. D. (2003). Knowledge culture: An explanation. Singapore: Pustaka National PTE.

${ }^{8}$ Al-Attas, S. M. N. (1991). The concept of education in Islam: a framework for an Islamic philosophy of education. Kuala Lumpur: ISTAC.

${ }^{9}$ Ibid 
10 Johnson, C. S., \& Hinton, Harvey, III. (2018). A morality of inclusion: A theoretical argument for culturally consonant character education. Curriculum and Teaching Dialogue, 20(1), 73-87,178.

${ }^{11}$ Manning, M. L. (1996). Young adolescents at risk: Introduction. The Clearing House, 69(4), 198.

${ }^{12}$ Doris, Dennis A. "Teaching moral education: Principles of instruction." Peabody Journal of Education 56, no. 1 (1978): 33-44.

${ }^{13}$ Herman, Barbara. "Moral literacy." Tanner lectures on human values 19 (1998): 311-374.

14 Anangisye, W. L. (2010). Promoting teacher ethics in colleges of teacher education in Tanzania: practices and challenges. African Journal of Teacher Education, 1(1): 64-77.

${ }^{15}$ Vokey, D. (1990). Objectivity and moral judgement: Towards agreement on a moral education theory. Journal of Moral Education. 19(1), 14-23.

16 Robert, C. (1989). States move forward on values education. Religion and Public Education. £6(3), 429-431.

${ }^{17}$ Miskawayh, I. 1968, Tahdhib al-akhlaq (The Refinement of Character). Beirut: Mansyuwwarat Dar Maktabah al-Hayah.

${ }^{18}$ Linda, \& Eyre, R. (1993). Teaching your children values. London: Simon \& Schuster. Malaysian Ministry of Education. (2004). A research report on social problems among secondary school students in FELDA. Kuala Lumpur: Education Planning and Research Department, Ministry of Education, Malaysia

${ }^{19}$ Phenix, Philip Henry. Realms of meaning: A philosophy of the curriculum for general education. McGraw-Hill, 1974. PP. 1-14

${ }^{20}$ Bashir, Samra, and M. Akhtar. "Exploring the Intellectual Contributions and Educational Thoughts of Syed Abul A'ala Maududi." Ma'arif Research Journal (2015).

${ }^{21}$ Wan Daud, W. (1998). The Educational Philosophy and Practice of Syed Muhammad Naquib Al-Attas: An Exposition of the Original Concept of Islamisation. Kuala Lumpur: International Institute of Islamic Thought and Civilization (ISTAC).

${ }^{22}$ Graham, Ellen. "The role of the teacher in moral education." (1978). P.39

${ }^{23}$ Muhammad, A. Q. (1978). The ethics of Al-Ghazali: A composite ethics in Islam. New York: Caravan Books.

24 Ahmad, V. D. (1983). 'Ulum Al-Qur'an: An introduction to the sciences of the Qur'an. United Kingdom: The Islamic Foundation.

${ }^{25}$ Bidmos, M. (1984). Religious teacher education: Islamic perspective. Muslim Education Quarterly, 2(1), 52-64

${ }^{26}$ Hassan, L. (1983). Teacher's role and some aspects of teaching methodology: Islamic approach. Muslim Education Quarterly, 1(1), 23-24.

${ }^{27}$ Azhar, M., \& Nasir, K. M. (2010). Moral development in mystical Islamic education in indo-Pak subcontinent: Sufism. Journal of Education and Sociology, 3, 4

${ }^{28}$ Al-Taftazani, M. I. U. (1986). Islamic education: Its principle and aims. Muslim Education Quarterly, 4(1), 66-74.

${ }^{29}$ Hadi, S. (1979). The Islamic as opposed to modern philosophy of education. In S. M. N. Al-Attas (Ed.), Aims and objective of Islamic education. Jeddah: King Abdul Aziz University.

${ }^{30}$ Diorio, J .A. (1985). The decline of history as a tool of moral training. History of Education Quarterly. 25(1), 71-101.

${ }^{31}$ Lukens-Bull, Ronald A. "Teaching morality: Javanese Islamic education in a globalizing era." Journal of Arabic and Islamic Studies 3 (2000): 26-47.

${ }^{32}$ Paolitto, Diana Pritchard. "The role of the teacher in moral education." Theory into practice 16, no. 2 (1977): 73-80.

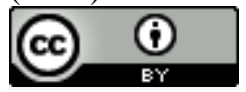

This work is licensed under a Creative Commons Attribution 4.0 International License. 